\title{
Compliance \& dexterity, factors to consider in home care and maintenance procedures
}

\author{
Adherencia e destreza: factores a considerar en \\ programas preventivos
}

\author{
Victoria Criado(a) \\ Andrew Tawse-Smith ${ }^{(b)}$ \\ (a) Universidad Central de Venezuela, \\ Venezuela. \\ (b) Colegio Odontologico Colombiano, \\ Colombia.
}

\begin{abstract}
Mechanical plaque control appears to be the primary means of controlling supragingival dental plaque build-up. Although daily oral hygiene practices and periodic professional care are considered the basis for any program aimed at the prevention and treatment of oral diseases, these procedures are technically demanding, time consuming and can be affected by the compliance and manual dexterity of the patient. Individual skills and acquired behavior patterns determine effectiveness of a preventive program and oral hygiene practice. Successful preventive programs and home care procedures clearly depend on the interaction and commitment between the dental professional and the patient. Identifying the capacity of the individual to comply with the professional recommendations and evaluating the dexterity of the patient to remove supragingival dental plaque will permit the implementation of an adequate preventive program and can help on the selection of adjunctive antimicrobial agents and devices needed to reach an effective oral care routine.
\end{abstract}

Descriptors: Oral hygiene; Patient compliance; Behavior; Motor skills; Preventive health services.

Resumen: El control de la placa dental parece ser el mecanismo primario para controlar el crecimiento de la placa dental supragingival. Aunque la práctica diaria de la higiene bucal y el cuidado profesional periódico, son considerados la base para cualquier programa dirigido a la prevención y tratamiento de las enfermedades de la cavidad bucal, estos procedimientos son técnicamente exigentes, consumen tiempo y pueden ser afectados por la aceptación y la destreza manual del paciente. Las destrezas individuales y los patrones de comportamiento adquiridos, determinan la efectividad de un programa preventivo y la práctica de la higiene bucal. El éxito de los programas preventivos y los procedimientos del cuidado bucal en el hogar dependen claramente de la interacción y compromiso entre el odontólogo y el paciente. La importancia de identificar la capacidad del individuo para cumplir con las recomendaciones y la evaluación de la destreza del paciente para remover la placa dental supragingival, permitirán la implementación de un adecuado programa de prevención que podría ayudar a la selección de un agente antibacteriano coadyuvante y los dispositivos necesarios para alcanzar una rutina de cuidado bucal efectivo.

Descriptores: Higiene bucal; Cooperación del paciente; Conducta; Destreza motora; Servicios preventivos de salud.
Received for publication on Nov 20, 2006 Sent for alterations on Dec 05, 2006 Accepted for publication on Jan 22, 2007 


\section{Introduction}

Several studies show that periodontal diseases can be controlled or minimized by utilizing supervised preventive programs. ${ }^{4,5,10}$ The introduction of preventive programs, as well as home care procedures, is based on the evidence that accumulation of dental plaque is associated with gingival inflammation (gingivitis), periodontitis and dental caries. The daily disruption of dental plaque by mechanical means, which include the use of toothbrush and interdental aids, appears to be critical in controlling the potential of dental plaque to cause related oral diseases and is the primary means of controlling supragingival dental plaque build-up. ${ }^{10,11}$ However, toothbrushing and flossing are difficult tasks, and most of the patients are not able to completely remove plaque in all teeth surfaces. Mechanical plaque control is also time-consuming, and some individuals may lack motivation for these procedures.

The aim of this paper is to review the literature about compliance and dexterity in home care and maintenance procedures.

\section{Mechanical methods of plaque control Manual toothbrushes}

Toothbrush size and design can vary, as well as their bristles length, hardness and disposition. The American Dental Association (ADA) has described the manual toothbrush admissible dimensions as follows: toothbrush surface length from $25.4 \mathrm{~mm}$ to $31.8 \mathrm{~mm}$; width from $7.9 \mathrm{~mm}$ to $9.5 \mathrm{~mm}$, presenting between two and four rows of bristles and between 5 and 12 bunches of bristles each row. ${ }^{33}$ However, most of the recent studies could not demonstrate superiority of one toothbrush design over others. ${ }^{13,14,31}$ Although several brushing techniques have been described in the literature, there is no evidence that one is superior to the others. ${ }^{17}$

\section{Electrical toothbrushes}

When correctly performed during the proper period of time, manual toothbrushing is highly effective, but most of the patients do not have the dexterity and motivation to remove dental biofilm. One approach to improve brushing motivation and skill is the use of an electrical toothbrush, which in some individuals can increase their interest in oral hygiene and improve their brushing skills. ${ }^{23}$

Studies evaluating electrical toothbrushes with counter-rotary movements show a dental plaque reduction from $63.6 \%$ to $98.2 \%$, and a gingival inflammation reduction from $35.5 \%$ to $77.2 \%$, when compared to traditional toothbrushes. ${ }^{24,41}$ On the other hand, studies assessing oscillating/rotating toothbrushes observed a dental plaque reduction from $16.1 \%$ to $79.8 \%$, and gingival inflammation reduction from $3.5 \%$ to $75 \% .^{2,16,22}$

It is relevant to emphasize that the advantages offered by electrical toothbrushes are more evident facing special situations, for instance in the case of patients with orthodontic appliances, older subjects and handicapped individuals, among others.

\section{Interdental plaque control}

The interdental area offers favorable conditions for the establishment and maturation of dental biofilm. Data have demonstrated that papillary gingivitis is more prevalent than buccal or lingual gingivitis, and that caries lesions on interproximal faces are more difficult to detect. ${ }^{15}$ Toothbrushing is not sufficient to control caries and periodontal disease in the interdental area. Therefore, additional techniques are necessary for plaque control ${ }^{3,7}$ and to maintain periodontal health ${ }^{8,19}$ in that area.

Several methods and devices are used for the removal of interdental plaque: dental flosses, dental wood sticks, interdental toothbrushes, special toothbrushes and a great variety of mechanical and electrical devices. Their indication should consider the patient's age, his or her susceptibility to gingivitis and to periodontal disease, previous history of periodontal disease, manual skill, knowledge and motivation. $^{25}$

Periodontal literature suggests that methods of interdental hygiene should be performed between 12 and 48 hours. Even though the "twice-a-day routine" is recommended, there is a consensus that the quality of this hygiene is more important than the frequency. Interdental hygiene methods, as well as their frequency, should be individualized according to the patient's needs. 


\section{Dental flossing and interdental toothbrushes}

Dental flossing is rarely used by the general population, possibly due to the lack of knowledge, and to the difficulty of use, time, and fear of injuries.

Interdental toothbrushes seem to be more acceptable by the population; however, their indication is limited to opened interproximal spaces. ${ }^{27}$ A study concluded that interdental brushes are preferable to floss for interdental plaque removal in patients suffering from moderate to severe periodontitis. ${ }^{12}$

\section{Compliance}

Although there are clear advantages to the introduction of oral preventive programs and home care procedures, behavioral and life-style factors can affect dental health and compliance levels. ${ }^{26}$ Several studies report different risk factors associated with lack of compliance and dexterity: personal behavior and personal belief (vulnerability to a disease) aspects, positively related self-esteem, awareness, faith in the efficacy of care, novelty of the oral hygiene aid coupled with the lack of familiarity, family size, lack of parental supervision and geographical area factors. ${ }^{1,20,21,28,29,30,32,34,37,39,40}$

Some studies have divided factors determining compliance into those determined by the dental professional and those determined by the patient. ${ }^{6,9}$ Dental professional factors such as communication skills, personal qualities and level of commitment have been related with the degree of compliance. On the other hand, attitudes toward disease, ability to understand instructions as well as communication skills have been classified among the patient related factors. Baker ${ }^{6}$ (1995) reported that the level of compliance decreases in situations where there is a higher number of oral hygiene aids used and as the treatment time and complexity of the oral hygiene task increases.

Another aspect to consider is frequency of oral cleaning. Addo-Yobo et al. ${ }^{1}$ (1991) reported in a Ghana schoolchildren population that awareness was strongly associated with the frequency of oral cleaning. In this study, $38 \%$ of the population in the urban area used toothbrush versus $8 \%$ in the rural area, demonstrating that children in the urban area were more aware, had cleaner mouths and consequently had lower needs for periodontal treatment. Likewise, family size and lack of parental supervision have been linked to reduced toothbrushing frequency; this was reported in English schoolchildren from 31 secondary schools. ${ }^{30}$ Similarly, other studies have reported that toothbrushing frequency is positively related to self-esteem, suggesting that females brush more frequently than males. ${ }^{28,29}$

Daily oral hygiene practices and periodic professional care are the foundations in any program aimed at the prevention and treatment of diseases. However, home care procedures are technically demanding, time consuming and can be affected by the compliance and manual dexterity of the individual. Freitas-Fernandes et al. ${ }^{18}$ (2002) reported limited effectiveness even after oral hygiene instructions were given to a group of Brazilian children with health hazards, poverty and lack of education. After 6 months, the group that received oral hygiene instructions still had $32 \%$ of the dental surfaces with dental plaque accumulation, indicating that both motivation of the individual and his/her manual dexterity in the use of oral hygiene aids influence the success of home care procedures. Similarly, Olsson ${ }^{32}$ (1978) showed limited compliance in a group of Ethiopian children that received oral hygiene instructions. At the end of the study, half of the children did not follow the instructions. Likewise, Tawse-Smith et al. ${ }^{38}$ (2002) also reported limited dexterity in elderly patients. The moderate effectiveness of self-performed oral hygiene practices in removing plaque from implant abutment surfaces was demonstrated after having oral hygiene instructions both with manual and electric toothbrushes.

Bakdash $^{5}$ (1995) showed that toothbrushing and the use of fluoride toothpastes are frequent. On the other hand, flossing, mouthrinsing and other oral hygiene measures were less common than toothbrushing, suggesting that only a small percentage of the population practice them regularly and that oral hygiene practices appear to be related to socioeconomic status, enabling factors, individual values, attitudes and lifestyles. Although dental floss has been shown to be effective, this mechanical aid is not frequently used. It is evident that the use of ad- 
junctive devices to clean interproximal spaces is affected by the complexity of the procedure and the time required performing it, as well as the fact that behavioral modification must be induced to achieve change.

It is clear from the literature that mechanical methods to control plaque may be supplemented when necessary with antiseptic agents. ${ }^{35,36}$ Nowadays, patients need more professional guidance in selecting the most appropriate oral health products and home care procedures based on the scientific evidence available for each one of them. It is the dental professional's responsibility to establish and reinforce patient's compliance with home care practices, and to objectively select products and procedures to

\section{References}

1. Addo-Yobo C, Williams SA, Curzon ME. Oral Hygiene practices, oral cleanliness and periodontal treatment needs in 12-year old urban and rural school children in Ghana. Community Dent Health. 1991;8:155-62.

2. Ainamo J, Xie Q, Ainamo A, Kallio P. Assessment of the effect of an oscillating/rotating electric toothbrush on oral health. A 12-month longitudinal study. J Clin Periodontol. 1997;24:28-33.

3. Axelsson P, Lindhe J. Effect of controlled oral hygiene procedures on caries and periodontal disease in adults. J Clin Periodontol. 1978;5:133-51.

4. Axelsson P, Nystrom B, Lindhe J. The long-term effect of a plaque control program on tooth mortality, caries and periodontal disease in adults. Results after 30 years of maintenance. J Clin Periodontol. 2004;31(9):749-57.

5. Bakdash B. Current patterns of oral hygiene product use and practices. Periodontol 2000. 1995;8:11-4.

6. Baker KA. The role of dental professionals and the patient in plaque control. Periodontol 2000. 1995;8:108-13.

7. Becker W, Berg L, Becker BE. Untreated periodontal disease: a longitudinal study. J Periodontol. 1979;50:234-44.

8. Bellamy P, Barlow A, Puri G, Wright KI, Mussett A, Zhou $\mathrm{X}$. A new in vivo interdental sampling method comparing a daily flossing regime versus a manual brush control. J Clin Dent. 2004;15:59-65.

9. Berndsen M, Eijkman MA, Hoogstraten J. Compliance perceived by Dutch periodontists and hygienists. J Clin Periodontol. 1993;20:668-72.

10. Cancro LP, Fischman SL. The expected effect on oral health of dental plaque control through mechanical removal. Periodontol 2000. 1995;8:60-74. improve compliance taking into account the individual's susceptibility and needs. Likewise, patients must understand the importance of communicating their limitations with given instructions, take responsibility and have a long-term commitment to their oral health, search for oral hygiene information and participate in educational and preventive programs.

\section{Conclusions}

Limited compliance by people as well as the difficulty in carrying out the different oral health procedures strongly suggest the importance of implementing adjunctive aids, such as antiseptic mouthrinses, to enhance mechanical plaque control measures.

11. Christersson LA, Zambon JJ, Genco RJ. Dental bacterial plaques. Nature and role in periodontal diseases. J Clin Periodontol. 1991;18:441-6.

12. Christou V, Timmerman MF, Van der Velden U, Van der Weijden FA. Comparison of different approaches of interdental oral hygiene: Interdental brushes versus dental floss. J Periodontol. 1998;69:759-64.

13. Claydon N, Addy M, Scratcher C, Ley F, Newcombe R. Comparative professional plaque removal study using 8 branded toothbrushes. J Clin Periodontol. 2002;29(4):310-6.

14. Claydon N, Leach K, Newcombe RG, Ley F, Scratcher C, Addy M. The use of professional brushing to compare 3 toothbrushes for plaque removal from individuals with gingival recession. J Clin Periodontol. 2000;27:749-52.

15. De la Rosa M, Zacarias Guerra J, Johnston DA, Radike AW. Plaque growth and removal with daily toothbrushing. J Periodontol. 1979;50:661-4.

16. Dentino AR, Derderian G, Wolf M, Cugini M, Johnson R, Van Swol RL et al. Six-month comparison of powered versus manual toothbrushing for safety and efficacy in the absence of professional instruction in mechanical plaque control. J Periodontol. 2002;73:770-8.

17. Egelberg J. Tooth brushing methods. In: Egelberg J. Oral hygiene methods: the scientific way. Synopses of clinical studies. $3^{\text {rd }}$ ed. Malmö: Odontoscience; 1999. p. 13-20.

18. Freitas-Fernandes LB, Novaes Junior AB, Feitosa AC, Novaes AB. Effectiveness of an Oral Hygiene Program for Brazilian Orphans. Braz Dent J. 2002;13(1):44-8.

19. Graves RC, Disney JA, Stamm JM. Comparative Effectiveness of flossing and brushing in reducing interproximal bleeding. J Periodontol. 1989;60:243-7. 
20. Haynes R. A critical review of the determinants of patient compliance with therapeutic regimes. In: Sackett D, Haynes R. Compliance with therapeutic regimes. Baltimore: Johns Hopkins University press; 1976.

21. Heasman PA, Jacobs DJ, Chapple IL. An evaluation of the effectiveness and patient compliance with plaque control methods in the prevention of periodontal disease. Clin Prev Dent. 1989;11:24-8.

22. Heasman PA, Stacey F, Heasman L, Sellers P, Macgregor ID, Kelly PJ. A comparative study of the Philips HP 735, Braun/ Oral B D7 and the Oral B 35 Advantage toothbrushes. J Clin Periodontol. 1999;26:85-90.

23. Hellstadius K, Asman B, Gustafsson A. Improved maintenance of plaque control by electrical toothbrushing in periodontitis patients with low compliance. J Clin Periodontol. $1993 ; 20: 235-7$

24. Killoy WJ, Love JW, Love J, Fedi PF Jr, Tira DE. The effectiveness of a counter-rotary action powered toothbrush and conventional toothbrush on plaque removal and gingival bleeding. A short term study. J Periodontol. 1989;60:473-7.

25. Kinane DF. The role of interdental cleaning in effective plaque control: Need for interdental cleaning in primary and secondary prevention. In: Lang NP, Attström R, Löe H, editors. Proceedings of the European Workshop on Mechanical Plaque Control. Berlin: Quintessence; 1998. p. 156-68.

26. Kuhner MK, Raetzke PB. The effect of health beliefs on the compliance of periodontal patients with oral hygiene instructions. J Periodontol. 1989;60:51-6.

27. Lobene RR, Soparkar PM, Newman MB. Use of Dental floss. Effect on plaque and gingivitis. Clin Prev Dent. 1982;4:5-8.

28. MacGregor ID, Balding JW. Self-esteem as a predictor of toothbrushing behavior in young adolescents. J Clin Periodontol. 1991;18:312-6.

29. MacGregor ID, Balding JW. Toothbrushing frequency and physical recreation in 14-year-old school children. Health Education J. 1989;48:89-91.
30. MacGregor ID, Balding JW. Toothbrushing frequency in relation to family size and bedtimes in English schoolchildren. Community Dent Oral Epidemiol. 1987;15:181-3.

31. McDaniel TF, Miller DL, Jones RM, Davis MS, Russell CM. Effects of toothbrush design and brushing proficiency on plaque removal. Compend Contin Educ Dent. 1997;18:572-7.

32. Olsson B. Efficiency of traditional chewing sticks in oral hygiene programs among Ethiopian schoolchildren. Community Dent Oral Epidemiol. 1978;6:105-9.

33. Perry D. Plaque control in the periodontal disease patient. In: Newman M, Takei H, Carranza F. Clinical Periodontology. $9^{\text {th }}$ ed. Philadelphia: W.B. Saunders Co.; 2002. p. 689-714.

34. Rayant GA, Sheiham A. An analysis of factors affecting compliance with tooth-cleaning recommendations. J Clin Periodontol. 1980;7:289-99.

35. Scheie AA. Modes of action of currently known chemical anti-plaque agents other than chlorhexidine. J Dent Res. 1989;68(Spec Iss):1609-16.

36. Sharma N, Charles CH, Lynch MC, Qaqish J, McGuire JA, Galustians JG et al. Adjunctive benefit of an essential oilcontaining mouthrinse in reducing plaque and gingivitis in patients who brush and floss regularly: a six-month study. J Am Dent Assoc. 2004;135(4):496-504.

37. Strack BB, McCullough MA, Conine TA. Compliance with oral hygiene instruction and hygienists' empathy. Dent Hyg (Chic). 1980;54(4):181-4.

38. Tawse-Smith A, Duncan WJ, Payne AG, Thomson WM, Wennström JL. Relative effectiveness of powered and manual toothbrushes in elderly patients with implant-supported mandibular overdentures. J Clin Periodontol. 2002;29:275-80.

39. Wilson TG Jr. Compliance and its role in periodontal therapy. Periodontol 2000. 1996;12:16-23.

40. Wilson TG Jr, Glover ME, Schoen J, Baus C, Jacobs T. Compliance with maintenance therapy in a private periodontal practice. J Periodontol. 1984;55:468-73.

41. Yukna RA, Shaklee RL. Evaluation of a counter-rotational powered brush in patients in supportive periodontal therapy. J Periodontol. 1993;64:859-64. 